UDC: $811.111^{\prime} 373.2 \quad$ https://doi.org/10.22190/JTESAP2003187O

\title{
NEONYM ANALYSIS IN THE ENGLISH LANGUAGE FOR TOURISM PURPOSES
}

\author{
Tina Orel Frank \\ University of Primorska, Faculty of tourism studies - Turistica, Department of Cultural Tourism, \\ Portorož, Slovenia \\ E-mail: tina.orel@fts.upr.si
}

\begin{abstract}
Languages are subject to constant change, with new lexis being just one, yet the most sensitive. Languages for specific purposes are no exception, and this is particularly true in areas that are currently undergoing rapid development, such as tourism. The aim of the research is to analyze neonyms in the English tourism language from the perspective of new lexicon-building processes. Neonyms are understood as terms in the neologistic phase of the lexical life cycle. The contribution extracts them according to their subjective timebound definition in the field of tourism based on the use of Internet sources as corpus, which is particularly suitable for the research of new language. The paper contributes to the understanding of tourism as a field and its specific language and sheds light on recent (often unsystematic) term formation processes. It shows indirect theoretical word formation tendencies, which are also applicable when comparing word formation processes in General English as opposed to the English language for tourism purposes.
\end{abstract}

Key words: neonym, term-formation processes, tourism, terminology

\section{BACKGROUND}

Languages are subject to constant change, with the new lexis being just one of them, but it is the most alive and therefore a mirror of the world that uses them (Halliday in Yallop 2007; Kecskes 2015). New expressions are shaped out of the need to fill the gaps in naming new things and concepts (Crystal 2003; Lehrer 2003: 371; Stojičić 2004; Gložančev 2009; Francl 2011: 417; Janssen 2013; Barrs 2015: 372), and out of the need to keep languages alive and diverse. Only a fragment (20\%) of the lexicon used in the English language a millennium ago is still in use, the rest having been altered by newly coined or borrowed expressions (Minkova and Stockwell, 2009). According to Fischer (1998: 7) "an investigation of lexical change must look at the new coinages in their social context and describe their possible dissemination against the background of relevant, actual events." As well as "language change may be explained by the same mechanisms that govern social diffusion of non-linguistic innovations" (Maybaum 2013: 152). Malenkina \& Ivanov (2018) define tourism as the dominant cultural industry and as one of the most important economic fields of activity under the effects of globalisation, which underlines the importance of language commodification in the sense of changing identities, interpersonal relationships and community structure modifications.

Submitted July $22^{\text {nd }}, 2020$, accepted for publication October $12^{\text {th }}, 2020$

(C) 2020 by University of Niš, Serbia | Creative Commons License: CC BY-NC-ND 
Tourism has become one of the leading and fastest developing global industries. Between January and June 2019, international tourist arrivals increased by $4 \%$ year-onyear (UNWTO 2019) and are projected to grow twice as fast in emerging market destinations as in advanced tourism economies (UNWTO 2016). Leisure and recreation have become more accessible as the growing part of the world's population is more urbanised, well-educated and with sufficient financial resources. New generations, such as millennials, value travel experiences more than the purchase of material products (Future Foundation 2016). Moreover, many new destinations, attractions and tourism markets are opening up. Tourism is also adapting to the new circumstances in terms of communication (Telfer \& Sharpley 2015). Dann (2012) noted that communication within the tourism discourse community has advanced from the phase of monologue to the current trialogue which means that the development of the Internet and globalisation at any given time means that a large part of communication is destined for all participants in the tourism discourse community. Communication is thus spread in all directions and has evolved from vertical, mono-linguistic information to a horizontal and participatory form (Francesconi, 2014: 27), especially with the development of social media (Sparks et al., 2013). This, according to Zalmont, Pappu and Thadani (2019: 425) resulted in an increased use of neologisms.

"The expansion of terminology in a branch of learning is stimulated by the progress of scientific discoveries within the field" (Stojičić 2004: 32). In the past, tourism was described as "indiscipline" (Tribe 1997), while tourism research was described as "stale, tired, repetitive and lifeless" (Franklin and Crang 2001. 5). Now it turns out that "tourism research is not a theoretical desert and that it has seen the emergence of new concepts, specific to the object studied" (Decroly and Diekmann 2018: 2). The question of whether tourism is an independent discipline is still open (Butowski 2016). Nonetheless, specific knowledge represented by concepts as mental entities called terms is present, and this is the main focus of this work. New forms of tourist expression not only arise from a denominative need to name new discoveries, concepts or subjects, but also result from a creative language development. The aim of this work is to analyse neonyms in the English tourism language from the perspective of new lexicological processes. They will be examined as a "temporary inventory" (Stojičić 2004. 34), as neonyms (more recent terminological candidates) from the field of tourism and thus treated as terms in the neologistic phase of lexical development over the last nine years. As terms they cannot (yet) fully comply with general terminological principles, they are not (yet) standardized.

As we have argued that new expressions define novelties in a society, culture, as well as disciplines, they "should be integrated into the vocabulary material offered to English learners" (Rets 2016: 813). The author (ibid) also argues that nevertheless the majority of studies on new words belongs to the field of linguistics rather than language teaching, these two areas are interconnected in several aspects. This paper thus presents a list of tourism neonyms with an explanation on their formation processes that are a useful material to be implemented in an ESP classroom for various reasons. They are a reflection on language as well as tourism development, helping students learn the "here and now" English language with the added bonus of understanding the processes behind the language development. 


\section{TOURISM TERMINOLOGY}

The one most defining characteristic of a certain field is its field specific lexis, denoting content information of a field, materialized in field specific language units called terms. In defining tourism terminology we refer to Vintar (2008: 37-39), who says that the only possible criteria for the definition is its function and its specialized use, stressing that there can be no formal and generally applicable criteria for the definition. Accordingly, Gabrovšek (2005: 16-17) defines terms as expressions that are bound to certain concepts in the field of a particular target field and form a subsystem of knowledge. As an update of the tourism terminology typology of Mikolič (2013: 258) we present a model of tourism terms based on the Hoffman model or as summarized by Vintar (2008: 38). Tourism terms are divided into three categories:

- tourism specific terms - terms that are exclusively coined and used in tourism, e.g. to touristify, undertourism);

- tourism transterms - terms that are common to many areas and that have passed among different fields in the process of transterminologization with or without semantic changes (e.g. destination management, peer-to-peer economy);

- tourism pseudoterms - terms that have been (or have not yet been) passed in the first two categories (e.g. winterscape, weekendismo, wefie, urbexing, sleepcation, genervacation, maximoon, earlymoon, dadvertising, hotumn, hamdog, flashpacker, dronfie, dark kitchen). Looking at the topic from a socio-terminological point of view and suggesting that terms should always be examined in their context, this category also includes all terms (although they do not follow the classical rules of terminology) from the general language used in the context of tourism. Tourism terms are pseudoprescriptive terms which, in contrast to prescriptive terms (coined in the natural sciences), are often not monosemantic, not established, non-economical, text nondependant, etc. All this makes their standardization difficult, and the connection between term, concept and definition is loose (Žagar Karer 2011: 39).

Tourism terms are specific from various reasons. Firstly, tourism is highly interdependent on other fields and disciplines and as such it is hard to specifically determine the sphere of its reach, as well as all the connections with other fields and disciplines (Bergenholz and Tarp 1995: 58). Secondly, tourism terminology does not always comply with the classic view on terminology due to the fact that tourism terms are deeply connected with the general lexis. Liverani \& Canals (2011 in Malenkina \& Ivanov, 2018) describe tourism discourse as the general language mixed with thematic components (like cuisine, art, history and economy). Thirdly, as an interdisciplinary field, it mixes with other fields and disciplines as well. Among individual specific languages there are constant interlanguage processes of expression passing. (De/trans)terminologizaton processes are used when languages try to cope with current constant changes and innovations induced by globalisation. Term passing among general and specific languages in tourism is a result of contemporary popularity of tourism topicality on all levels. With the processes of expression passing (de/trans-terminologizaton) terms are in constant relation among the three layers of tourism discourse community (professionals, tourists and tourees). Forthly, tourism terminology tends to be internationalised and globalized due to the core practice of tourism, meaning, the process of language borrowing is common, but Cabre (1998: 88-90) stresses that borrowed terms are often misused in the recipient language system. This is observable in languages which predominantly borrow terminology from global languages, mainly from English, and fail to establish standardized and uniformed language units. Due to tourism being a globalised industry and an extremely fertile field as an 
industry as well as a discipline, new concepts emerge frequently and terminology often lacks behind in naming them in a standardized manner. As a result of the actualization of tourism, the intrusion of foreign language elements and a high level of (de/trans) terminology, tourism terminology mainly faces two issues that Kalin Golob and Logar (2008) define within the concepts of unambiguity and systemicity: different terms are used to name the same content and the same terms for different content.

\section{NEONYMS}

Neonyms are neologisms that are bound to a specific field and its discourse. The classification of general and terminological neologisms (neonyms) results from the study of these neologisms in different language systems, contexts and fields of application. New expressions are not only bound to general languages, but also occur in specific languages. Cabré (1998) speaks of the lexical neology of general language (general neology or only neology) in the lexical neology of specialised languages (specialised neology, terminological neology or neonymy).

Since neologisms are characterised above all by their spontaneity and do not necessarily require new lexical creations for the purpose of naming a new concept, neonyms are coined out of the denominative need to fill a terminological gap. The denotative meaning denotes new (recently invented or newly discovered) things and concepts (Rets 2016 and Ulanova 2014). Necessary expressions, as the first lexicalizations of new objects and concepts fill a gap in language and are likely to spread and be stored in the mental lexicon (MacKenzie 2014). They have a high probability of entering a lexical system, since they are rarely formed as synonyms for already existing words. Such cases are usually a consequence of inconsistent use of terms. Neonyms tend to be rather stable, monosemantic, without synonyms, neutral and free of connotations. They are especially relevant in one specialised field (Hormingo 2012).

Neonyms are terms in the neologistic phase of the lexical life cycle. Neologisms are most often described as newly coined words or phrases or as those that have overcome a recent semantic change (Oxford Dictionary; Collins Cobuilt Dictionary; Cambridge Advanced Learner's Dictionary; Newmark 1995; Muhvić-Dimanovski 2005; Algeo 1991: 2; Simeon 1969: 904-905). They must be defined according to the subjective attitude of each researcher (Rey 1995; Cabré 1998) and are very time-dependent (what was considered new ten years ago does not necessarily have to be perceived as such today). Due to the complexity of the relationship between old and new neologisms and thus neonyms, their definition can only be understood according to several separate or overlapping approaches (Cabré 1998: 445):

- diachronic approach defines neologism as a lexeme that has only recently emerged, is fairly well established, but has lost the status of a nonce- word (Toporišič 2000: 130; Fischer 1998);

- psychological approach defines neologisms as expressions that are stylistically marked as new by the members of a particular discourse community (Rey 1995; Fischer 1998; Cabre 1998; Csak 2011; Anesa 2018);

- lexicographic approach defines neologisms as newly coined expressions that have not yet been lexicalized - not yet registered in dictionaries (Algeo 1991; Sanders 2010 in Rets 2016; Ficher 1998; Kerremans 2015);

- system approach, defining neologisms as lexemes that exhibit both formal (morphological, graphical and phonetic) and semantic instability.

When defining neonyms, none of the approaches should be considered in isolation. For example, dictionaries are not stable, wide enough, regularly updated sources to be a 
defacto signal of an expression that is in the neologistic phase. In this research, neonyms are English tourism terms in their neologistic phase of the lexical life cycle. This means that they are always considered here as 'only' potential terms that have passed their nonce- word development stage (they are used more than three times - a number defined by Csak (2011), are institutionalised (fairly established) but not yet lexicalized (not listed in tourism terminological dictionaries), or terminologically standardised and stylistically marked as new by the tourism discourse community.

\section{TERM FORMATION PROCESSES}

Neonyms share the formation processes with the general lexicon, therefore they are analysed here according to the formation processes of neologisms. Cabré et al. (2012), for example, divide neonyms, like general neologisms, into two large groups according to their origin: those that have arisen through the emergence of new knowledge/behaviour within a particular language, and those that are transferred from other languages through the transfer of knowledge from other language groups. However, some of the causes in term formation may occur more frequently in comparison to the general vocabulary. Jemec Tomazin (2010: 163) describes that terms are formed predominantly by intralingual (metaphorical) transfer, transfer from other languages and calques. Vintar (2008) points out the combination of phrases in the context of intralingual acquisition in terminology.

In Table 1 we define a typology of neologisms in relation to origin. There are, according to one of the dividing lines, two basic forms of formation of new expressions which can also emerge according to the second dividing line as denominative/expressive or stylistic/aesthetic neologisms:

- intralingual acquisition (original neology): a) new formation in systemic or nonsystemic ways of word formation, b) vocabulary shifts: necessarily semantic, where it is a matter of adding meaning to already existing words, and not necessarily semantic, where it is a matter of shifting outdated lexicons, grouping into multi-word units, or shifts between general and field-specific languages, or between field-specific languages, where words transfer and do not necessarily change meanings;

- interlingual acquisition (secondary neology).

Table 1 Term formation processes of neonyms with respect to origin

\begin{tabular}{|c|l|c|}
\hline \multicolumn{2}{|c|}{ Intralingual } & \multicolumn{1}{c|}{ Interlingual } \\
\hline New coinages & \multicolumn{1}{c|}{ Shifts } & \multirow{2}{*}{ Citation form } \\
Systematic coinages & Semantic shifts & \\
& Metaforisation & Calque \\
& Metonimisation & \multirow{2}{*}{ Loanword } \\
& Non-necessarily semantic shifts: & \\
& Reactualisation & \\
& Revitalisation & \\
& Combining in multi-word units & \\
& Terminologisation & \\
& Determinologisation & \\
& Transterminologisation & \\
\hline
\end{tabular}




\section{NEONYMS IN AN ESP CLASSROOM}

Introducing new expressions from a certain field can enhance students' understanding of the field's development in general. This paper provides a list of tourism neonyms to be introduced to students as mirrors of tourism development and sheds light on most common term formation processes in the language of tourism, which is particularly beneficial for advanced English learners. Hence it functions as a presentation of a linguistic study with an ESP teaching developmental aim.

The paper supports the implementation of neonyms in the English for tourism purposes classroom, but the advice can be used in all ESP subjects, as the topic can be used on all language levels. The general use of neologisms or neonyms helps students understand the development of the language community or a certain discipline coining the new expressions, thus unraveling the changes in society. It is noteworthy that especially advanced English learners can benefit from the understanding of term formation processes in neonyms from their field. Gong and Hong (2019) mention that analysing the word-formation mechanisms or strategies of neologisms learners can not only reinforce their understanding about the unique linguistic features of the language that they acquired before but also obtain a better understanding of the social and cultural aspects that shape a certain language. Nevertheless, the mentioned authors research the learning process of the Chinese language, so the statement can be applied to all languages. Also Rets (2016) points out that more advanced students could be more interested in the laws of language development and hence neologisms can be taught according to the factors that motivated their formation.

\section{NEONYM COLLECTION AND ANALYSIS}

This research draws attention to term formation processes in tourism neonyms. The selection of neonyms, later analysed in terms of term formation processes, was compiled using corpus-driven research that extracted neonyms using the Internet as a corpus best suited for the extraction and analytical study of lexical novelties, according to Gložančev (2009: 17) and Michelizza (2015: 57 and 66). It was based on the assumption of Paryzek (2008: 164), as he noted on the basis of his and other research, that neologisms tend to appear after certain phrases, namely '(so)called', '(also) known as' in English or quotation marks. To test whether the expressions are perceived as new by the tourism discourse community, a Delfi analysis was also conducted. This part of the research was determined in November 2019 and is described in detail in the doctoral dissertation English and Slovene Neologisms in the Language of Tourism (Orel Frank, 2019). The mentioned research was carried out with a purpose of gathering new terminology from the field of tourism in a glossary. The whole list of gathered English new tourism expressions is also presented as an Appendix 1 (available at: https://docs.google.com/document/d/1R7irPZA1GpsD41mEt2zeDlUoSWLy8DBS9tu5ps WSalk/edit?usp=sharing) to this article. As Table 2 shows, it extracted 290 English tourism neologisms (152 one-word neologisms, 124 multi-word neologisms and 14 acronyms). In terms of word classes, the picture is rather typical of terms where most neologisms are nouns. 
Table 2 English tourism neologisms

\begin{tabular}{|l|c|}
\hline & English \\
\hline One-word neologisms & 152 \\
& (139 nouns, 10 adjectives and 3 verbs) \\
\hline Multi-word neologisms & 124 \\
\hline Acronyms & 14 \\
\hline Sum & 290 \\
\hline
\end{tabular}

Among the collected English neologisms, our research from the point of view of word formation also shows a typical picture of the frequency of use of English word formation methods. The most common feature, which is also characteristic of technical languages, is the compounding process, which is considered in the context of semantic shifts in the sense of the more recent word formation English theory, which understands the English compounding process as a semantic shift or use of words for other purposes (repurposing), i.e. the combination of two words to form a new lexeme with a new meaning (O'Dell 2015: 2). In this category tourism terminology expanded especially in combinations designed to denote new tourism types, forms, concepts, etc. Our research encountered a long list (62!) of those appearing in "adjective + tourism" or "noun + tourism" forms: e.g. adventure tourism, anthropocene tourism, beauty tourism, black tourism, disaster tourism, ethical/ethic tourism, experimental tourism, family tourism, fertility tourism, film tourism, film-induced tourism, food tourism, genealogical tourism, grief tourism, health tourism, historic tourism, medical tourism, memorial tourism, non-vital medical tourism, religious/faith tourism, reproductive tourism, residential tourism, pop-culture tourism, post-disaster tourism, transplant tourism, war tourism, wildlife tourism. This phenomenon was in the past already observed by Rata (2012) under the term adjectival tourism, which refers to various forms of tourism that have emerged.

Compounding is followed by affixation. With the implementation of a semantic view in combination of the term formation one, selected neonyms showed a list of clipped forms reappearing with or without a semantic change in many expressions by the use of several term formation processes (blending, clipping or affixation). These forms are a phenomenon called libfixes. Blends are very common as well. There are also some acronyms and loanwords. As an example of back formation, only one noun (famil> familiarization) was recorded, derived from the phrase familiarization trip. The verb cowork (from co-working) was also formed as a back formation. In the following segments we give attention to the unsystematic processes most frequent in tourism term formation procedures.

\subsection{Coinages derived from tourism}

The development of several possible word-forming abilities in naming is due to the intensive popularization of an object or phenomenon (Žele, 2010: 132). The fact that tourism is a current topic is reflected in our research by the appearance of coinages derived from tourism: to turistify, touristification, anti-tourism, overtourism, post-tourism. The suffix cation gave rise to the noun turistification, which describes the process of the emergence or implementation of tourism in a place. 


\subsection{Abbreviations}

Abbreviations are common among the English neonyms in our study. Since these are newly created abbreviations, they usually appear with an explanation in brackets: $D M C$ (destination management company), DMO (destination management organization), $F B B$ (family business brand), FIT (fully independent traveler/tourist or foreign independent tour/ traveler), ITO (inbound tour operator), OTA (online travel agency), OTO (outbound tour operator), (pay per click), RTBS (real-time booking system), TTA (traditional travel agent). There are also examples of compounds with an abbreviated first part: GPS hiking, VR tour.

\subsection{Blending}

According to Bauer (2002), blends are combinations of clips or whole words, whereby Lehrer (2007: 117-119) adds that the parts blended are not necessarily equivalent, and lists many different ways of blending. Mattiello (2013) on the other hand distinguishes blends from clipped compounds and demonstrates in particular that a large number of non-uniform denominations indicate a not (yet) entirely clear picture of blends and their related forms in English word formation, although he claims the same as Lehrer (2007) and Plag (2003) above, that they can be understood as compounds from the original point of view, since they have more than one basis of merging. Nevertheless, the process of blending was detected as fruitful in the creation of tourism pseudoterms, which indicates that the process is less used in academic and professional circles. There were cases where both lexemes are clipped and blended (e.g. netnography (internet + ethnography), urbexing (urban + exploring); and cases where only one is clipped (e.g. histourism (history + tourism), militourism (military + tourism), commjacking (communication + jacking), glocalisation (global + localisation), homesitting (home + babysitting), foodventure (food + adventure), educrafting (educational + crafting), footicial (foot + facial), genervacation (generation + vacation). It is worth mentioning that inside the process of blending there appeared several analogy strings. The analogy in English word formation processes is described by Mattiello (2017, 2018), who, nevertheless, defines it as a special word formation process in which a new word is formed according to the model of another existing word or in a series of prototype words that share the same word formation process. This is closely tied to the formation with the use of libfixes, described in the forthcoming paragraph. One of the analogy strings derived out of brunch (breakfast + lunch) actually showed the instability of the blending process in English by offering as many as three examples of blends of identical or semantically related words: linner (lunch + dinner), lunner (lunch + dinner), lupper (lunch + supper).

\subsection{Libfixes}

A libfix was first defined by Arnold Zwicky (2010) as a clip of an established word, freed from its original and added to other words with the aim of creating a new expression. Vidovič Muha (2011: 296) describes it broadly as newly emerging defining contents, which are also interesting as internationalisms, since they occur in several languages. With regard to libfixes, the semantic view of affixes is emphasized, as they can be clipped from the original word and added to new ones to form a new expression by keeping their original meaning (as edu- > educational) or changing it (-holic > workaholic). As far as the word formation process is concerned, "libfixes are parts of words that share properties with both 
blends, compounds and affixes" (Norde \& Sippach 2019: 353). Therefore, we consider libfixes primarily from a semantic point of view as a form of detachment (retaining their original meaning) or alienation (changing their meaning) from the original word in the form of a clip in order to attach it to another word. They are time-bound to the time in which they are topical and contribute above all to the formation of schematic analogies. In our analysis, we found a frequent use of the following libfixes:

- gastro-

Our analysis detected frequent use of the gastro- as a detached libfix: e.g. in gastroanomie (otherwise originally French), gastro-attraction, gastrobrand, gastronout.

- pro-

Pro- (from professional) appears several times: e.g. protecture (professional + protecturus - Latin) in terms of the professional protection of personal data online offered by companies; prosumption (professional + consumption) in terms of semi-professional consumption; prosumer (professional + consumer) in the sense of a semi-professional consumer.

- - packer

The detached -packer (from backpacker) appears in: begpacker, bratpacker, flashpacker.

- - moon

English libfix -moon (from honeymoon) is particularly interesting in this context. We detected it in a schematic analogy in a series of new English expressions: jobbymoon, earlymoon, maximoon, minimoon, mommymoon, daddymoon. There have been extensions of meaning (similar to the pronoun -holik) with respect to the meaning of the original word honeymoon. As a clipped form, it is widely used today, i.e. also for trips/vacations, which are not necessarily honeymoons (jobbymoon). When a particular element becomes so widely accepted that people use it frequently, it can lose its connection with its original word and become an independent morpheme, according to Lehrer (2007: 121). The transition from a newer fragment to a new productive morpheme is a gradual diachronic process with intermediate stages, most often involving semantic reinterpretation and generalization (Mattiello 2018), which also happened in the -moon case.

- eco-

Among the fertile libfixes in English, we find the content eco-, which Voršič (2013) classifies as a polyphonic prefix. As a detached libfix in our research in English, ecoappears in: ecosystem services, ecomuseum, ecologisation, eco-management, eco-conscious and eco-metropolis, and as a unifying content in ecophobia (with a meaning broader than ecological, namely on fear of the familiar home environment).

\section{5 (De/trans)terminologization processes}

Within these processes our research came to prove a statement by Mikolič and Beguš (2011: 315) who find that in the field of tourism, terminologization is the most common term formation process, because due to the specifics of the complex activity of tourism, which extends beyond professional and scientific language, in which the general public intervenes, general vocabulary assumes a specific meaning and becomes a term. As an example of terminologisation, that often occurs together with metaphorization (e.g. sales funnel). 
Determinologisation is the reverse process, although we must emphasize that here we are no longer talking only about the directions of transition of terms, but terminologizing is the naming of something new using a term from general vocabulary (often a metaphor), and determinologizing is expanding the visibility of denotation from specific to general lexicon (Vidovič Muha 2000: 116-177). As for example, the neonym scattered hotel (also: diffused hotel, dispersed hotel, virtual hotel), previously used only by the tourism professionals.

The process of transterminologisation (also: reterminologisation Žagar Karer (2011) / broader terminologisation Žele (2012: 113) marks the transition of terms between disciplines or specialized fields. Tammerman (2000) finds that terms are no longer strictly tied to the frameworks of one profession, but move through the contents of different disciplines, most often those that are related, or at least partially consistent in content. The authors merely name the same process differently, where the denotation retains its basic meaning, but minor, especially semantic, changes are possible (Bidnenko 2013). The interdisciplinary nature of tourism accepts terms from a wide range of disciplines and specialized fields (e.g. marketing experience marketing, FBB (family business brand); sociology - glocalization; sports - sup, etc.). Transterms can semantically adapt to the transferring field or retain the original meaning. A multidisciplinary term with the same meaning in several fields is, for example, the term glocalization, which can be described and researched by several disciplines or disciplines, each from its own point of view, also, the term global healthcare, the meaning of which in tourism logically differs from that enlisted in medical terminological dictionaries.

\subsection{Interlinguality}

Many authors have already researched the phenomenon of contact languages also on the examples of the language of tourism (Dann 1996; Francesconi 2007; Cappeli 2013; Gandin 2014; Dumitrascu 2017; Karpova 2019).

English today has a great influence on other languages, but foreign language influences can also be traced among the more recent lexicon of tourism. The terms come from different languages:

- Greek: eletheromania (fanatical desire to travel), hodophile (someone who loves to travel);

- Swedish: livsnjuture (someone living a full life), resfeber (feeling uncomfortable before traveling);

- Danish: onism (awareness of an individual that he/she will visit/feel only a small part of the world in his/her life);

- German: fernweh (desire for distant places; desire to travel);

- Italian: latte (levy) (tax on non-refundable plastic coffee pots in the UK);

- Spanish: jinterismo (illegal or partially legal activities related to tourism in Cuba prostitution, pimping, unlicensed guides or taxi drivers, etc.);

- Japanese: yugen / Yügen (a deep, mysterious feeling at the beauties of the universe).

- The adoption of foreign language terms to describe well-being, philosophy of life, and terms more directly related to tourism is on the rise in English in general. 


\section{CONCLUSION}

The paper contributes to the understanding of tourism as a field and its specific language and sheds light on recent (often unsystematic) term formation processes in tourism and in general. The total of 290 English tourism neonyms were analysed with regard to their creation process. English is a global language with a large effect on other languages, the tourism terminology broadens its list with interlingual acquisition, especially inside the topics of well-being or philosophy of life. An intralingual perspective reveals a rather typical picture of the use term formation processes. As in many other terminological systems, compounding and repurposing were proven to be most fruitful, including a long list of adjectival tourism forms. The more recent processes, that were particularly evident in the analysis, were presented in detail. The process of blending proved to be still unstable and was mainly used in pseudoterm creation, including the use of libfixes, which tend to generate new analogy strings, with the use of other word formation processes as well. Nevertheless, it cannot be claimed that the term formation processes used in tourism neonyms necessarily differ from those used in other disciplines or fields. A comparative study between different fields could be the next research step.

This paper contains a list of tourism neonyms to be presented to students as a mirror of tourism development, highlights the most common term formation processes in the language of tourism, which is particularly beneficial for advanced learners of English, and aims to promote the implementation of the topic of language novelties in an ESP classroom. Therefore, it acts as a presentation of a linguistic study with the purpose of developing the teaching of ESP. The latter statement, however, goes hand in hand with the fact that the monitoring and proper enforcement of new concepts is a "moral obligation of a profession and its experts to their own and external public" (Verhovnik 2002: 755), which was achieved in collaboration between linguists and LSP lecturers.

It could be argued that the implementation of neonyms in an ESP classroom is irrelevant, since we are dealing with unstable units for which it is just as difficult to predict whether they will remain parts of the language fond or disappear quickly. But the paper was built on the idea that language is a living entity that reflects our time, and we strongly believe that it should be presented to students as such. The question that remains open for any language teacher is whether to use neonyms as a separate learning unit or integrate them into other subject areas.

\section{REFERENCES}

Algeo J (ed.). 1991. Fifty Years Among the New Words: A Dictionary of Neologisms, 1994-1991. Cambridge: CUP.

Anesa, P. 2018. Lexical Innovation in World Englishes: Cross fertilization and Evolving Paradigms. London, New York: Routlege.

Barrs, K. 2015. Catachrestic and Non-Catachrestic English Loanwords in the Japanese Language. In Abstract Book of Corpus Linguistics, edited by Formato, F. \& Hardie, A., 372-374. Lancaster: UCREL.

Bauer, L. 2002. English Word-Formation. Cambridge: Cambridge University Press.

Bergenholz, H. \& Tarp, S. 1995. Manual of Specialised Lexicology: The Preparation of Specialised Dictionaries. Amsterdam in Philadelphia: John Benjamins Publishing Company. 
Bidnenko, N. P., 2013. Modern Tendencies in the Process of Term Formation. News of Dnepropetrovsk University named after Alfred Nobel 1 (5). 205-210.

Butowski, L. 2016. Tourism as a Discipline in the light of non-classical sociology of science. Journal of Tourism and Cultural Change, 16(4), 436-454.

Cabré, M. T. 1998. Terminology: Theory, Methods and Applications. Amsterdam, Philadelphia: John Benjamins Publishing.

Cabré, M. T. Estopa Bagot, R. \& Chelo Vargas, S. 2012. Neology in specialized communication. Terminology 18(1). 1-7.

Crystal, David (ed.), 2003. The Cambridge Encyclopedia of the English Language. Cambridge: Cambridge University Press.

Csak, E. 2011. The Translation of Neologisms in Special Terminology. Translation Journal 5(3). Available at: http://translationjournal.net/journal/57neologisms.htm. (Accessed on 16.4.2013).

Dann, G. 2012. Remodelling a changing language of tourism: from monologue to dialogue and trialogue, PASOS, 4 (10), 59-70.

Decroly, J.-M. \& Diekman A. 2018. The Production of Tourism Concepts. Via Tourism Review, 13, 1-7. Available at: https://journals.openedition.org/viatourism/2725. (Accessed on 3. 3. 2020).

Fischer, Roswitha, 1998. Lexical Change in Present-Day English: A Corpus Based Study of the motivation, Institutionalization and Productivity of Creative Neologisms. Tübinger: Gnv.

Francesconi, S. 2014. Reading Tourism Texts: A Multimodal Analysis. Bristol: Channel View Publications.

Francl, M. 2011. Neolexia. Nature Chemistry, 3, 417-418.

Franklin, A. \& Crang, M. 2001. The trouble with tourism and travel theory? Tourist studies, 1(1). 5-22.

Future Foundation. 2016. Millennial Travel Report. Available at: https://www.foresightfactory.co/wp-content/uploads/2016/11/Expedia-MillennialTraveller-Report-Final.pdf. (Accessed on 5. 11. 2018).

Gložančev, A. 2009. Analitična osvetlitev novejše slovenske leksike. In Novejša slovenska leksika (v povezavi s spletnimi jezikovnimi viri), edited by Gložančev, A., Jakopin, P., Michelizza, M., Uršič, L. \& Žele, 9-35. A. Ljubljana: Založba ZRC, ZRC SAZU.

Gong, W. \& Hong, H. 2019. Using Corpus-based Analysis of Neologisms on China's New Media for Teaching Chinese as a Second or Foreign Language. In Computational and Corpus Approaches to Chinese Language Learning, edited by Lu X., Chen B., Chinese Language Learning Sciences. Springer, Singapore.

Halliday, M. A. K. \& Yallop, C. 2007. Lexicology: A Short Introduction. London: Continuum.

Hormingo, M. T. D. 2012. Lexical Creation and Euphemism: Regarding the Distinction Denominative or Referential Neology vs. Stylistic or Expressive Neology. Lexis - EJournal in English Lexicology 7. Available at: https://journals.openedition.org. (Accessed on 31. 7. 2018).

Janssen, M. 2013. Lexical gaps. In Chapelle, C. A. The Encyclopedia of Applied Linguistics. Blackwell Publishing. Available at: http://onlinelibrary.wiley.com/ doi/10.1002/9781405198431.wbeal0693/full. (Accessed on 15.1. 2014).

Jemec Tomazin, M. 2010. Slovenska pravna terminologija: od začetkov v 19. stoletju do danes. Ljubljana: Založba ZRC, ZRC SAZU. 
Kerremans, D. 2015. A Web of New Words: A Corpus-Based Study of the Conventionalization Process of English Neologisms. Frankfurt am Main: Peter Lang.

Lehrer, A. 2003. Understanding Trendy Neologisms. Italian Journal of Linguistics. 15 (1), 271-384.

Lehrer, A. 2007. Lexical Creativity in Texts: Advertising and the Media. In Lexical Creativity, Texts and Contexts, edited by Munat, J., 114-134. Philadelphia: John Benjamins Publishing Company.

MacKenzie, I. 2014. Lexical innovation: cromulently embiggenin a language. Alicante Journal of English studies. 27 (2014). 91-105.

Malenkina, N. \& Ivanov, S. 2018. A Lingusitic Analysis of The Official Tourism Websites of the Seventeen Spanish Autonomous Communities. Jounal of Destination Marketing and Management, 9, 204-233.

Mattiello, E. 2013. Extra-grammatical Morphology in English. Berlin in Boston: Walter de Gruyter.

Mattiello, E. 2017. Analogy in Word-Formation: A Study of English Neologisms and Occasionalisms. Berlin in Boston: Walter de Gruyter.

Mattiello, Elisa, 2018. Paradigmatic Morphology: Splintes, Combining Forms and Secreted Affixes. SKASE Journal of Theoretical Linguistics, 15 (1), 2-22.

Maybaum, R. 2013. Language Change as a Social Process: Diffusin Patterns of Lexical Innovations in Twitter. Berkley Linguistics Society, 39, 152-166.

Michelizza, M. 2015. Spletna besedila in jezik na spletu: Primer blogov in Wikipedije v slovenščini. Lingua Slovenica. Ljubljana: Založba ZRC, ZRC SAZU.

Mikolič, V. 2013. Področni govor in terminologija na primeru jezika turizma. In Infrastruktura slovenščine in slovenistike, Obdobja 32, edited by Žele, A., 255-261. Ljubljana: Znanstvena založba Filozofske fakultete.

Minkova, D. \& Stockwell, R. P. 2009. English Words: History and Structure. Cambridge: Cambridge University Press.

Muhvić-Dimanovski, V. 2005. Neologizmi. Problemi, teorije i primjene. Zagreb: Zavod za lingvistiku, Filozofska fakulteta Sveučilišta v Zagrebu.

Newmark, P. 1995. A Textbook of Translation. New York: Prentice Hall.

Norde, M. \& Sippach, S. 2019. Nerdalicious scientainment: A network analysis of English libfixes. Word Structure. 12 (3). 353-384.

O'Dell, F. 2015. Creating new words: affixation in neologisms. ELT Journal 70 (1). 1-6.

Orel Frank, T. 2019. Angleški in slovenski neologizmi v jeziku turizma. University of Ljubljana, The Faculty of Arts. Doctoral dissertation.

Paryzek, P. 2008. Comparison of selected methods for retrieval of neologisms. Investigationes Linguisticae, 14 (2008). 163-181.

Plag, I. 2003. Word-Formation in English. Cambridge: Cambridge University Press.

Rets, I. 2016. Teaching Neologisms in English as a Foreign Language Classroom. Procedia - Social and Behavioral Sciences, 232 (2016), 813-820.

Rata, G. 2012. Adjectival Tourism. A Case Study. In The English of Tourism, edited by Rata, G., Petroman, I. \& Petroman, C., 3-18. Newcastle upon Tyne: Cambridge Scholar Publishing.

Rey, A. 1995. Essays on Teminology. Amsterdam: John Benjamins Publishing.

Sanders, E. 2010. Nooit meer uitslapen. Kleine kroniek van het moderne gezinsleven. Veen, 10de herziene editie.

Simeon, R. 1969. Enciklopedijski rječnik lingvističnih naziva. Zagreb: Matica hrvatska. 
Sparks, B., H. Perkins \& Buckley R. 2013. Online travel reviews as persuasive communication: The effects of content type, source, and certification logos on consumer behaviour. Tourism Management, 39, 1-9.

Stojičić, V. 2004. Sociolinguistic stimuli to the development of the English lexicon language contact and social need. Linguistics and Literature, 3(1), 29-36.

Toporišič, J. 2000. Slovenska slovnica. Maribor: Založba Obzorja.

Tribe, John, 1997: The Indiscipline of Tourism. Annals of Tourism Research ,24 (3), 638-657.

Telfer, D. J., \& Sharpley, R. 2015. Tourism and development in the developing world. (2nd ed.). Oxon: Routledge.

Ulanova, S. 2014. Affix semantics (terms vs. neologisms). Terminology Science in Russia today: From the Past to the Future, 116, 389.

UNWTO. 2016. Tourism Highlights. 2016 Edition. Available at: https://www.eunwto.org/doi/pdf/10.18111/9789284418145. (Accessed on 20. 1. 2019).

UNWTO. 2019. UNWTO World Tourism Barometer and Statistical Annex. Available at: sitcon.singidunum.ac.rs/. (Accessed on 13. 11. 2019).

Verhovnik, T. 2002. Slovensko izrazje odnosov z javnostmi. Teorija in praksa, 39 (5), $755-765$.

Vidovič Muha, A. 2000. Slovensko leksikalno pomenoslovje: govorica slovarja. Ljubljana: Znanstveni inštitut Filozofske fakultete.

Vidovič Muha, A. 2011. Slovensko skladenjsko besedotvorje. Ljubljana: Znanstvena založba Filozofske fakultete.

Vintar, Š. 2008. Terminologija: Terminološka veda in računalniško podprta terminografija. Ljubljana: Znanstvena založba Filozofske fakultete v Ljubljani.

Voršič, I. 2013. Sistemska in nesistemska leksikalna tvorba v novejšem besedju slovenskega jezika. Maribor: Univerza v Mariboru, Filozofska fakulteta.

Zalmont, N., Pappu, A. \& Thadani, K. 2019. Unsupervised Neologism Nominalization Using Embedding Space Mapping. Proceedings of the 2019 EMNLP Workshop WNUT: The 5th Workshop in Noisy User-Generated Text. 425-430. Hong Kong: Association for Computational Linguistics.

Zwicky, A. 2010. Libfixes. Available at: https://arnoldzwicky.org/2010/01/23/libfixes/. (Accessed on 16. 11. 2018).

Žagar Karer, M. 2011. Terminologija med slovarjem in besedilom. Analiza elektrotehniške terminologije. Ljubljana: ZRC SAZU.

Žele, A. 2010. Pomenotvorne zmožnosti z vidika /de/terminologizacije (v slovenščini). In Terminologija in sodobna terminografija, edited by Ledinek, N. \&, Žagar Karer, M. \& Humar, M., 125-139. Ljubljana: Založba ZRC, ZRC SAZU.

Žele, A. 2012. Pomensko-skladenjske lastnosti slovenskega glagola. Ljubljana: ZRC SAZU. 